Boston University School of Law

Scholarly Commons at Boston University School of Law

Faculty Scholarship

$1-2015$

\title{
The Economics of Class Actions and Class Action Waivers
}

Keith N. Hylton

Boston University School of Law

Follow this and additional works at: https://scholarship.law.bu.edu/faculty_scholarship

Part of the Law and Economics Commons

\section{Recommended Citation}

Keith N. Hylton, The Economics of Class Actions and Class Action Waivers, in 23 Supreme Court Economic Review 305 (2015).

Available at: https://scholarship.law.bu.edu/faculty_scholarship/157

This Article is brought to you for free and open access by Scholarly Commons at Boston University School of Law. It has been accepted for inclusion in Faculty Scholarship by an authorized administrator of Scholarly Commons at Boston University School of Law. For more information, please contact lawlessa@bu.edu. 


\section{HEINONLINE}

DATE DOWNLOADED: Tue Sep 20 20:54:08 2022

SOURCE: Content Downloaded from HeinOnline

Citations:

Bluebook 21st ed.

Keith N. Hylton, The Economics of Class Actions and Class Action Waivers, 23 Sup. CT. ECON. REV. 305 (2015).

ALWD 7th ed.

Keith N. Hylton, The Economics of Class Actions and Class Action Waivers, 23 Sup. Ct.

Econ. Rev. 305 (2015).

APA 7th ed.

Hylton, K. N. (2015). The Economics of Class Actions and Class Action Waivers.

Supreme Court Economic Review, 23, 305-340.

Chicago 17th ed.

Keith N. Hylton, "The Economics of Class Actions and Class Action Waivers," Supreme Court Economic Review 23 (2015): 305-340

McGill Guide 9th ed.

Keith N. Hylton, "The Economics of Class Actions and Class Action Waivers" (2015) 23

Sup Ct Econ Rev 305.

AGLC 4th ed.

Keith N. Hylton, 'The Economics of Class Actions and Class Action Waivers' (2015) 23

Supreme Court Economic Review 305

MLA 9th ed.

Hylton, Keith N. "The Economics of Class Actions and Class Action Waivers." Supreme Court Economic Review, 23, 2015, pp. 305-340. HeinOnline.

OSCOLA 4th ed.

Keith N. Hylton, 'The Economics of Class Actions and Class Action Waivers' (2015) 23

Sup Ct Econ Rev 305

Provided by:

Fineman \& Pappas Law Libraries

-- Your use of this HeinOnline PDF indicates your acceptance of HeinOnline's Terms and Conditions of the license agreement available at https://heinonline.org/HOL/License

-- The search text of this PDF is generated from uncorrected OCR text.

-- To obtain permission to use this article beyond the scope of your license, please use: Copyright Information 


\section{The Economics of Class Actions and Class Action Waivers}

Keith N. Hylton*

Class action litigation has generated a series of recent Supreme Court decisions imposing greater federal court supervision over the prosecution of collective injury claims. This group of cases raises the question whether class action waivers should be permitted on policy grounds. I examine the economics of class actions and waivers in this paper. I distinguish between the standard one-on-one litigation environment and the class action environment. In the standard environment, waivers between informed agents enhance society's welfare. In the class action environment, in contrast, not all waivers are likely to enhance society's welfare.

\section{INTRODUCTION}

Class action litigation has generated a series of Supreme Court decisions imposing greater federal court supervision over the prosecution of collective injury claims. In $A T \Theta T V$ Concepcion, ${ }^{1}$ the Court held that the Federal Arbitration Act preempted California's application of unconscionability doctrine as a bar to the enforcement of an agreement prohibiting class-wide arbitration. In Wal-Mart $\mathrm{V}$ Dukes, ${ }^{2}$ the Court rejected an effort to certify a discrimination class

\footnotetext{
* Boston University, knhylton@bu.edu. For helpful comments I thank Jennifer Arlen, Bob Bone, Chris Drahozal, Paul Gugliuzza, Benjamin Ogden, David Rosenberg, and Abe Wickelgren.

${ }^{1}$ ATe) TV Concepcion, 563 US 321 (2011).

${ }^{2}$ Wal-Mart v Dukes, 131 S Ct 795 (2011).
}

C 2016 by the University of Chicago. All rights reserved. 978-0-226-16666-7/2016/0023-0015\$10.00 
consisting of 1.5 million female employees of Wal-Mart, because the evidence was insufficient to prove the existence of a company-wide discrimination policy. In the most recent case, American Express Co $v$ Italian Colors Restaurant, ${ }^{3}$ the Court held that an arbitration agreement that effectively waived class actions-by relegating all disputes to a one-on-one arbitration process-was not inconsistent with the enforcement of rights under the Sherman Act.

These cases raise the question whether class action waivers should be permitted on policy grounds. The answer to this depends on the conditions under which class actions are socially desirable in the first place, and whether waiver agreements would harm society by eliminating some class actions.

With these questions in the forefront, this Article examines the economics of class actions and waivers of class actions. Its focus is on the welfare economics of class litigation-that is, the conditions under which the class action device enhances (or reduces) society's welfare. It also examines the welfare consequences of class action waiver agreements, and of agreements to individually arbitrate claims. As a general rule, the private and the social incentive to litigate diverge; plaintiffs may bring lawsuits under conditions in which litigation reduces society's welfare. The same is true of class actions.

I distinguish between the standard one-on-one litigation environment and the class action environment. In the standard environment, waivers between informed agents enhance society's welfare. ${ }^{4}$ The reason is that litigation waivers occur when, and only when, the deterrence benefit from litigation - that is, the degree to which the threat of litigation reduces injury costs more than injury-avoidance costsis less than the overall cost of litigation.

In the class action environment, by contrast, not all waivers are likely to enhance society's welfare. Because of the special economic circumstances of the class action environment, waivers may be exchanged between informed agents even when they are not socially desirable. The key features that distinguish class actions from standard one-on-one litigation are two: the existence of a class size threshold below which a class action becomes uneconomical (class viability threshold), and the existence of a common precaution or injuryavoidance action that applies uniformly to the entire class. These features create opportunities for inefficient waiver agreements among informed agents.

\footnotetext{
${ }^{3}$ American Express Co v Italian Colors Restaurant, 133 S Ct 2304 (2013).

${ }^{4}$ Keith N. Hylton, Agreements to Waive or to Arbitrate Legal Claims: An Economic Analysis, 8 Sup Ct Econ Rev 209 (2000).
} 
In spite of the incentive divergence problem in class action waiver contracting - that is, that the private and the social incentive to waive the right to class litigation may diverge-I conclude that a general prohibition on the enforcement of class action waivers may not be socially desirable. In a potentially large set of cases, class action waivers among informed agents are socially desirable, just as in the standard one-on-one litigation scenario. Indeed, within this set of cases, waiver agreements optimize the class action mechanism, by generating the greatest level of deterrence for every dollar invested in litigation.

The key variable in distinguishing the effects of class action waivers is the class viability threshold. If the efficient class size is so large that it is unlikely that a potential class action defendant can secure the number of waivers necessary to push the class size below the viability threshold, then waivers are likely to be efficient. If, on the other hand, the potential defendant has a reasonable chance of securing enough waivers to push the class size below viability, then inefficient waivers may be observed. In order to regulate class action waivers optimally, courts should identify the circumstances in which such agreements are likely to reduce society's welfare, and circumscribe enforcement only in those circumstances. A general prohibition on enforcement of class action waivers would be far too blunt for this task.

In the antitrust context, the case for regulating class action waivers is perhaps stronger than in any other setting. The conditions that generate inefficient waiver agreements, the economic need to have a class of sufficient size and the presence of a common injurious action, are clearly present in price-fixing cases. Even though attorneys' fees are shifted under the antitrust laws, expert fees are not, and thus there is a danger that waivers may push the victim class size below the viability threshold. ${ }^{5}$ However, even here the case for a blanket refusal to enforce waiver agreements is not compelling. Given the presence of public enforcement, it is not clear that waivers would substantially reduce incentives to comply with the law. The strength of the case for nonenforcement is also a function of the ability of victims to coordinate and the preclusive effect of the waiver contract.

\footnotetext{
${ }^{5}$ One might argue on first impression that this danger should be slight, in the light of the fee-shifting provisions of the federal antitrust laws. However, the feeshifting provisions do not allow prevailing plaintiffs to shift the full costs of experts to defendants; see In re American Express Merchants' Litigation, 667 F 3d 204, 218 (2d Cir 2012).
} 
In any event, the primary goal of this paper is to set out a framework for evaluating the welfare effects of class actions and of class action waivers. The greater part of this paper is an effort to classify types of class actions that are more or less likely to be conducive to inefficient waiver agreements. ${ }^{6}$ I conclude by applying the model to several topics in the literature on class actions.

\section{ILLUSTRATION}

The model developed here is quite simple in comparison to most models of the economics of litigation. Still, an even simpler example can be used to convey its core lesson. Suppose a potential victim considers signing, before any dispute arises, an agreement to waive his right to sue a potential injurer-for example, it could be a skier considering whether to sign a contract waiving tort liability against a ski resort. The individual will consider the benefits and costs to himself if he signs the contract, and the potential injurer will consider the benefit he gets from securing one waiver. If the parties are informed, the waiver contract enhances the parties' joint welfare.

The welfare implications of waiver in the class action setting are a bit more complicated. Suppose there are 200 potential victims, each of whom may suffer an injury of $\$ 1$, and the cost of proving liability to the entire class, if the injuries occur, is $\$ 100$. This would be an economically viable class action-the total damage award, $200 \times \$ 1=$ $\$ 200$, exceeds the cost of litigation, $\$ 100$. The class viability threshold is 100. If the injurer signs waiver agreements with 101 of the potential victims, the size of the victim class drops to 99 , which is short of the viability threshold. As a result, the injurer evades the threat of a class action suit. In effect, the 101 st victim waives for all of the remaining 99 victim victims who have not signed waiver agreements.

If the 101st victim to bargain with the injurer could bargain on behalf of the remaining 100 victims (himself included), he would have the proper incentives to set a price for the waiver. Since he does not bargain on behalf of the group, and is likely to consider only his own benefits and costs from signing the waiver, his private incentive to accept a waiver exceeds the social incentive to waive.

\footnotetext{
${ }^{6}$ Inefficient waivers of litigation are explored in Hylton, 8 Sup Ct Econ Rev 209 (cited in note 4), and Ehud Guttel and Shmuel Leshem, Bargaining around Cost-Benefit Standards, 103 J Pub Econ 55 (2013). Potentially inefficient waivers of class litigation are explored in Shay Lavie, The Malleability of Collective Litigation, 88 Notre Dame L Rev 697 (2013). This Article, in contrast, incorporates class waivers within a welfare analysis of litigation and of waiver agreements, and identifies conditions under which class waiver agreements may be efficient (or inefficient).
} 
Consequently, class litigation waiver agreements may be signed even when they reduce the welfare of all parties collectively. No assumption of strategic bargaining is necessary for this inefficiency outcome. The key is the divergence in the private and the social incentive to waive for the pivotal victim who sits at the class viability threshold.

The inefficiency result seems even more likely when the potential injurer bargains strategically. The strategic injurer knows that he faces a special opportunity when he bargains for a waiver with the pivotal victim (that is, the 101st victim he bargains with). Given the possibility of escaping the class action threat altogether, such an injurer will offer a premium for the individual waiver from the pivotal victim, because it will preclude litigation from all remaining victims.

This example leaves out several features that should be considered, such as a delineation of the terms of an efficient waiver agreement in the individual and in the class litigation settings, and the scope for efficient class litigation waiver contracts. The model below develops these features.

\section{WELFARE ECONOMICS OF LITIGATION}

\section{A. Standard One-on-One Litigation Model}

In this part, I review some basic lessons from the literature on the welfare economics of litigation. ${ }^{7}$ The literature has focused on the standard one-on-one litigation model, in which one plaintiff sues one defendant and there are no common issues that would justify class litigation. After reviewing the lessons in this setting, I will explore the welfare economics of class litigation.

There are two agents, injurer and victim, both risk-neutral. The injurer can take care to avoid injuring the victim, and taking care is costly. If the injurer takes care, there is still a risk that he will injure the victim. If the injurer does not take care, the risk that he will injure the victim is higher than when he does take care.

This description of the relationship between injury and precaution easily encompasses intentional injuries. Consider, for example, fraud. The injurer who commits fraud chooses between committing fraud, or forbearing from the commission and thereby forgoing the profit he could make from the fraud. The cost of "taking care"

\footnotetext{
7 See, for example, Steven Shavell, The Social versus the Private Incentive to Bring Suit in a Costly Legal System, 11 J Leg Stud 333 (1982); Keith N. Hylton, The Influence of Litigation Costs on Deterrence under Strict Liability and under Negligence, 10 Intl Rev L \& Econ 161 (1990).
} 
is simply the cost of forbearance, which is the profit that could be made from committing the act of fraud.

Since taking care is costly, the injurer will not do so unless the alternative, failing to take care, is even more costly. The threat of litigation guarantees that a decision not to take care will be more costly to the injurer than a decision to take care. Although the victim may not win his lawsuit against the injurer, the financial burden of litigation defense plus the expected cost of paying for the victim's injury are sufficient to lead the injurer to view taking care as more economically prudent than not taking care.

The following variables define basic components of the model:

$p=$ probability of injury when injurer does not take care

$q=$ probability of injury when injurer does take care

$V=$ loss

$X=$ cost of care

$c_{d}=$ injurer's cost of litigation

$c_{p}=$ victim's cost of litigation

I will assume liability is strict. If, instead of strict liability, I assumed that liability is based on negligence, none of the important results of this analysis would be altered.

I assume, in addition, that taking care is socially desirable, which means that the social loss avoided by taking care exceeds the cost of taking care, $(p-q) v>X$, and that the lawsuit has a positive expected value, $v>c_{p} .{ }^{8}$ Given that the victim will sue and win in response to an injury, the cost the injurer bears when he takes care is the sum of the cost of taking care, the expected liability to the victim, and the expected cost of litigation defense: $x+q c_{d}+q v$. The cost the injurer bears when he does not take care is the sum of the expected liability and the expected cost of litigation defense: $p v+p c_{d}$. Since the social loss avoided through care exceeds the cost of care, and the expected litigation defense cost is greater when the injurer does not take care, the injurer will take care.

Shavell showed that litigation is socially desirable when and only when the deterrence benefit from litigation exceeds the cost of

\footnotetext{
"I use the term "positive expected value" to contrast with the term "negative expected value" lawsuit, which has been used in the literature on litigation; see, for example, Robert Bone, Civil Procedure: The Economics of Civil Procedure (Foundation 2003). In this case, there is no need to use "expected value" because the outcome of the lawsuit is not uncertain. However, I use the term anyway to remain with terms familiar in the literature on the economics litigation. The same terminological approach is adopted in Thomas Ulen, An Introduction to the Law and Economics of Class Action Litigation, 32 Eur J L \& Econ 185 (2011).
} 
litigation: $(p-q) v-\mathrm{x}>q c_{d}+q c_{p} \cdot{ }^{9}$ Since the private decision to sue is based entirely on whether the claim has a positive expected value, private and social incentives to litigate diverge.

Why might the deterrence benefit be less than the expected cost of litigation? Litigation could generate overdeterrence-where the cost of precaution is greater than the losses avoided. Alternatively, the deterrence benefit may be positive yet so small, because precaution is unproductive, that it is swamped by litigation costs. Precaution will be unproductive in settings where additional care by the injurer has a negligible impact on expected harms, which could be due to precaution's ineffectiveness in changing the probability of harm or to the extremely low level of harm. Consider, for example, a ski resort. After a certain level of precaution is attained, additional precaution by the resort owner will have little impact on the probability that a skier will be injured-injury is an inherent risk of the sport.

\section{B. Waiver}

The victim may choose to waive his right to sue by selling it to the injurer. If the victim sells his right to sue to the injurer, the injurer will no longer take care. Thus, the victim can expect to suffer, after selling his right to the injurer, the harm associated with careless conduct by the injurer, $p v$. However, selling the right enables the victim to forgo the expense of suing, $q c_{p}$. The victim also forgoes the compensation he would receive for any injuries that might have occurred when he possessed the right to sue, but that compensation merely offsets the injuries suffered. It follows that the minimum price asked by the victim to waive his right to sue is equal to the expected harm less the avoided litigation cost, $p v-q c_{p}$.

For the injurer, purchasing the waiver allows him to avoid the cost of taking care, in addition to the cost of litigation and compensation. Thus, the maximum price the injurer will offer for a litigation waiver is $x+q v+q c_{d}$.

The injurer and victim will enter into a litigation waiver agreement when the asking price of the victim is less than the offer price of the injurer, ${ }^{10}$ which is equivalent to the condition under which litigation is socially undesirable. Thus, if transaction costs are low,

'Shavell, $11 \mathrm{~J} \mathrm{Leg} \mathrm{Stud} \mathrm{at} \mathrm{333-339} \mathrm{(cited} \mathrm{in} \mathrm{note} 7$ ).

${ }^{10}$ This ignores strategic considerations that might prevent the victim and injurer from entering into a waiver agreement even when the asking price is less than the offer price. At this stage of the analysis I have no interest in complicating the basic model by incorporating strategic issues. 
the right to litigate will be waived when and only when litigation is socially undesirable. ${ }^{11}$ Private and social incentives to litigate diverge only when transaction costs are so high that waiver agreements cannot be effected.

Among informed agents, waiver agreements will be executed when the productivity of care is low, when the cost of taking care is high, and when the cost of litigation is high. Taking care may be socially desirable, but if litigation costs are sufficiently large, the net benefit to society from the care induced by the threat of litigation may be outweighed by the cost of litigation. ${ }^{12}$

Consider again the ski resort example. Since there is little that the owner of a ski resort can do to substantially reduce the risk of injury to skiers, the deterrence benefit from litigation is likely to be considerably smaller than the joint cost of litigation. One should expect skiers and resort owners to execute waiver agreements, which is what one often observes.

\section{LITIGATION AND WAIVER OF CLASS ACTIONS}

Class actions require some modifications of the basic model presented above. The class action scenario often involves a lawsuit that has a positive expected value if brought by a large group seeking damages, but a negative expected value if brought by one individual. For example, suppose a financial institution skims off pennies from the accounts of thousands of customers. The total damage claim might be sufficient to justify a lawsuit by the entire class of customers, but the injury to any one customer, only pennies, would be insufficient to justify a lawsuit.

In the model immediately below I assume that the lawsuit has a negative expected value if brought by one individual. In a later part, I consider positive-expected-value class actions.

\section{A. Litigation Cost Structure and Incentives to Sue}

The plaintiff (victim) alleges a common wrong to an entire class. In addition to the common wrong, there may be some idiosyncratic,

\footnotetext{
${ }^{11}$ This is established in Hylton, 8 Sup Ct Econ Rev at 209 (cited in note 4).

${ }^{12}$ Recall that this assumes that the victim's threat to sue is credible because the lawsuit has a positive expected value. If the victim's threat to sue is not credible, the injurer will not offer to pay for a waiver agreement, and will not take care in the absence of a credible threat of a lawsuit. This "no lawsuits" outcome is socially inefficient when the deterrence benefit from litigation is greater than its cost.
} 
special way in which the defendant's conduct injured each victim of the class. The cost of litigation for any plaintiff consists, then, of proving liability based on the common wrong and particular features unique to his case.

Given this, the litigation cost for plaintiff $i(i=1, \ldots, N)$ is of the form $c_{p i}=C_{p}+W_{p i}$, where $C_{p}$ is the cost of the common component of proof and $W_{p i}$ is the cost of the idiosyncratic component of proof in the plaintiff's case. ${ }^{13}$ The cost of the class lawsuit, $c_{p N^{\prime}}$ is the sum of all of the idiosyncratic components and the common component: $c_{p N}=C_{p}+W_{p 1}+W_{p 2}+\ldots+W_{p N}$. The common component's cost is greater than the injury to the victim, $v<C_{p}$. Since each victim has a negative expected value claim, no victim will have an incentive to bring suit. ${ }^{14}$

The class action aggregates the injuries of the victims. If the class size is sufficiently large $N_{V}>c_{p N^{\prime}}$ so the class lawsuit will have a positive expected value. In effect, the class action device spreads the cost of the common component among all victims, so that the cost of litigation to each victim is effectively $c_{p N} / N$. It follows that there is a class viability threshold $\tilde{N}$, such that $v=c_{p N} / \tilde{N}$. When the class size falls below the viability threshold level $(N<\tilde{N})$, no individual will have an incentive to bring suit.

The defendant's litigation cost in a class action has a structure parallel to that of the plaintiff class: $c_{d N}=C_{d}+W_{d 1}+W_{d 2}+\ldots+W_{p N^{*}}$ The total financial burden of class litigation for the defendant is $N V+c_{d N^{*}}{ }^{15}$

${ }^{13}$ Yeon-Koo Che and Kathryn E. Spier, Exploiting Plaintiffs through Settlement: Divide and Conquer, 164 J Institutional \& Theoretical Econ 4 (2008), present a similar model of the structure of class action litigation costs, though their model assumes the existence only of the common component. I have included the idiosyncratic term to facilitate application of the formal model to the case law.

${ }^{14}$ This assumes that the common cost component cannot be shared among several individual lawsuits. If the common component can be shared in a manner that replicates the class action mechanism, then the existence of the common component will not preclude any claims. As long as cost sharing is more expensive or difficult in the absence of the class action mechanism, the basic structure of this model remains useful for examining class actions.

${ }^{15}$ Since the payoff to the class from the lawsuit, $N V-c_{p N^{\prime}}$ is less than the total financial burden of litigation for the defendant, the contract zone for settlement is not empty. Whether lawsuit settles depends on the extent of informational disparities and strategic bargaining incentives-for a survey, see Bone, Civil Procedure (cited in note 8 ). While the model implicitly assumes all cases litigate, it can be modified to take settlements into account by multiplying $c_{d N}$ and $c_{p N}$ the fraction of lawsuits that are litigated. 


\section{B. Precaution Technologies and Lawsuit Types}

An important feature of class action environment is that the care the injurer must take to avoid harming members of the class can have the same structure as just presented for the cost of litigation. In other words, in some settings there is a common, or centralized, component of care. Consider, for example, a fire escape in an apartment building. The landlord's decision to install an escape, or to maintain it, is a precaution that affects all or a substantial share of the tenants roughly equally. As a general matter the cost of taking care can be described as consisting of a common component and an individualized or idiosyncratic component-that is, $X+X_{i}$, where $X$ is the common component of care and $x_{i}$ is the idiosyncratic part.

This framework points to four litigation scenarios. In the first, the common component of litigation proof (or litigation cost) is zero and the common component of care is also zero. This is the standard one-on-one litigation scenario modeled in the literature as well as in the previous part. In the second, the common component of litigation is zero (idiosyncratic proof of liability) and the idiosyncratic component of injurer care is zero (common care). In this scenario, proof of negligence is straightforward and the same for each victim, because there is a common precaution technology, but there is an additional component of the lawsuit-for example, proof of victim care or proof of damages - that is costly to determine and varies substantially among victims. An example that falls in this category is a failure-to-warn lawsuit in which the negligence of the drug seller is absolutely clear, but the class of victims consists of some people who took reasonable care for their own safety and others who did not. ${ }^{16}$ In the third scenario, the idiosyncratic component of litigation cost is zero (common proof) and the common component of care is zero (idiosyncratic care). Such a structure might be observed where the injurer must determine the level of care to each potential victim (idiosyncratic care), but there can be a common failure that prevents the injurer from meeting the optimal idiosyncratic care levels-for example, in the case where a firm adopts a policy that is harmful to its consumers or to its employees, but its implementation depends on the uncoordinated conduct of many low-level manag-

\footnotetext{
${ }^{16}$ Of course, even if the drug seller's negligence is clear, the plaintiffs will still be expected to prove their case at trial, and this implies $C_{p}$ is greater than zero. But if the common question is one for which the evidence is overwhelming, the cost of proof should be minimal, and the burden may be shifted to the defendant on grounds, similar to res ipsa loquitur doctrine, that the circumstantial evidence of negligence is sufficient to submit the case to the jury.
} 
Table 1. Litigation Scenarios.

\begin{tabular}{lcc}
\hline & $\begin{array}{c}\text { Idiosyncratic Proof } \\
\text { of Liability }\end{array}$ & $\begin{array}{c}\text { Common Proof } \\
\text { of Liability }\end{array}$ \\
\hline Idiosyncratic Care & $\begin{array}{c}\text { Scenario 1: standard } \\
\text { one-on-one litigation model } \\
\text { Scenario 2: litigation } \\
\text { Come-on-one or class actions) }\end{array}$ & Scenario 3: class actions \\
\hline
\end{tabular}

ers, as alleged by plaintiffs in Wal-Mart. ${ }^{17}$ In the fourth scenario, the idiosyncratic component of litigation is zero, as is the idiosyncratic component of care. This is the scenario in which the injurer sets a common care level for all of the victims-for example, installing a fire escape for apartment tenants - and the proof of violation and of the amount of damages is the same for each plaintiff. Price-fixing by competing firms is another example that falls within the fourth scenario.

Many lawsuits probably fall somewhere between the various cells of Table 1 ; that is, some combination of idiosyncratic and common care, and some combination of idiosyncratic and common proof of liability. Moreover, it is easily possible for a lawsuit that involves a substantial common component of proof to also involve substantial idiosyncratic questions. Still, consideration of the scenarios in Table 1 can generate insights that can be applied to the more realistic mixed scenarios.

\section{Waiver of Class Actions}

Here I consider incentives to waive the right to bring a class action. The simplest way to proceed is to examine Scenario 3, the Wal-Mart type of class action, in which the common component of proof is responsible for the primary part of litigation costs and the care decision by the injurer is idiosyncratic. This type of class action is closest in structure to the one-on-one litigation scenario considered previously. Also to simplify, I will assume that there are no strategic considerations that influence waiver negotiations. The injurer and

\footnotetext{
${ }^{17}$ Under the plaintiff's theory of Wal-Mart, the employer had adopted a common policy of discrimination (common action), but its implementation depended on the actions of thousands of midlevel store managers (idiosyncratic action). The Supreme Court rejected the plaintiff's theory on the ground that there was insufficient evidence of a company-wide policy of discrimination.
} 
the victim are assumed to consider only the joint costs and benefits of a waiver agreement, not external costs or benefits. I will introduce additional complexity as the discussion proceeds.

In the absence of the option to bring a class action lawsuit, the threat to sue would not be credible, because $v<C_{p}$. Given the absence of a credible threat to sue, no injurer would have an incentive to take care, and for the same reason no injurer would have an incentive to purchase a waiver.

When the class action device is available, and the class size is above the viability threshold, each victim has a credible threat to sue, because $v>C_{p} / N$. Given the existence of a credible threat to sue, the injurer will have an incentive to take care and to purchase a waiver offered at a sufficiently low price. A class action waiver will be purchased when the price demanded by a victim to waive his class right is less than the price offered by the injurer to purchase the right. Since care is individually determined, the price demanded by the victim is $p_{V}-q\left(C_{p} / N\right) .^{18}$

The price offered by the injurer depends on the precaution costs avoided and his perception of the litigation costs avoided by waiving a class action claim. If the class size is above viability, the injurer avoids only a small portion of the class action defense cost by waiving one potential claim, which I will assume approximated by $C_{d} / N \cdot{ }^{19}$ Given the assumption of idiosyncratic care, the cost the injurer avoids by getting a waiver from one victim is $x+q v+q C_{d} / N$. A class action right will therefore be waived when:

$$
(p-q) v-x<q\left(C_{p} / N+C_{d} / N\right) .
$$

${ }^{18}$ I treat $C_{p} / N$ as the effective cost of the class action suit for the plaintiff. This assumes that the aggregate cost of the lawsuit is spread evenly among the plaintiffs. If the cost is not spread evenly among the plaintiffs then the cost of the class action for each plaintiff will be some fraction of $C_{p^{\prime}}$ greater or less than $1 / N$. I assume an equal share rule applies in this analysis, but other sharing rules are possible of course. Moreover, the sharing rule adopted has implications for the stability of the class action. On allocation rules and stability in class actions, see Joshua C. Teitelbaum, Allocation Rules and the Stability of Mass Tort Class Actions Georgetown Law Faculty Paper 1068 (May 6, 2010), online at SSRN: http://ssrn.com/abstract=1241018 (last visited Nov 17, 2015); Yeon-Koo Che, Equilibrium Formation of Class Action Suits, 62 J Pub Econ 339 (1996).

${ }^{19}$ The change in the defendant's common element cost resulting from one waiver is the marginal cost $\Delta C_{d} / \Delta N$. Use of average cost $C_{d} / N$ as an approximation of the marginal cost is based on two assumptions: (a) that the common element defense cost increases with the size of the class, which is plausible given that a defendant has a stronger incentive to invest in defense as the class size increases: see Ulen, 32 Eur J L \& Econ 185 (cited in note 8); and (b) the marginal cost goes to zero as the class size increases. 
It follows that when the class size is above viability, an agreement to waive the class action right will be socially beneficial when the deterrence benefit of class litigation is less than expected litigation costs for the marginal claim. Like waivers in the ordinary litigation setting, class action waivers are driven by the costs of litigation and the productivity of precaution.

\section{Victim Heterogeneity}

I have assumed so far that all members of the class are the same in terms of the nature of their legal claims, the effect of precaution on their risks of injury, and their injuries. If all victims are the same, then if waiver is efficient for one, it will be efficient for all; and if waiver is inefficient for one, it will be inefficient for all.

But class members may be heterogeneous. More precisely, the deterrence benefit from precaution may vary across potential victims. The effect of precaution on the risk faced by a potential victim may vary across victims. The cost of precaution may vary across victims. These differences may lead to an outcome in which a waiver agreement is efficient only for a subset of the potential victims.

Suppose the level of harm differs among class members, ranging from the smallest harm level, $v_{N^{\prime}}$ to the greatest harm, $v_{1}$. A class action lawsuit will be economically viable when the sum of harms is greater than the cost of class litigation: $V_{1}+\ldots+v_{N}>C_{p}$. Equivalently, class actions will be threatened credibly as long as the average harm within the class is greater than $C_{p} / N$. The class viability threshold is the class size at which the sum of harms is equal to the cost of plaintiff class litigation, or, equivalently, the class size at which the average harm is equal to $C_{p} / N$. For simplicity, I will continue to treat $C_{p} / N$ as the individual victim's cost of class suit.

A waiver will be exchanged between the injurer and victim $i$ when $(p-q) v_{i}-x<q\left(C_{p} / N_{i}+C_{d} / N_{i}\right)$, where $N_{i}$ represents the size of the subclass consisting of victim $i$ and those whose harms are greater. ${ }^{20}$

${ }^{20}$ This assumes that both potential plaintiff and potential defendant know the value of $v_{i}$, which may not be true in many settings. Specifically, the potential defendant may not have sufficient information to determine $v_{i^{\prime}}$ which may impede the formation of a mutually beneficial exchange between the two. The potential defendant may use some proxy for potential plaintiffs who have similar characteristics within identifiable subclasses. For example, an employer may suspect that all employees who work within a specific job classification are likely to have similar losses. The employer may therefore offer the same waiver terms to employees within that subclass, even though their individual losses are likely to vary around the mean for the subclass. Moreover, if the burden of avoidance $x$ is large relative to the harm $V_{i}$, variation in vi will not affect the contract terms much. The fact that the potential 
Thus, victims who have suffered the greatest harm levels will not be able to enter into mutually beneficial waiver contracts-because the price they demand exceeds the amount the injurer is willing to pay. Only those victims with relatively small harms will enter into efficient waiver contracts.

1. Efficient Class Action Waivers. As long as the class size remains above viability, all efficient class action waivers will be executed. The litigants who do not waive will retain their class action rights. To see this, order all potential class members from lowest to highest harm, and then choose a cutoff $V_{N^{*}}$ satisfying the condition $(p-q)$ $v_{N^{*}}-X=q\left(C_{p} / N^{*}+C_{d^{\prime}} / N^{*}\right)$. The efficient class size, $N^{*}$, is the number of class members with $V_{i}>V_{N^{*}}$. Waivers will be executed for all of the potential victims for whom $V_{i}<V_{N^{*}}$. At the efficient class size, the deterrence benefit from class litigation, on the margin, is equal to the cost of class litigation. Because of this, the efficient class size is the number of class members that maximizes the net social benefits provided by class litigation. See Figure 1.

In short, assuming a class size above the efficient level initially, waivers will bring the class size down to the efficient level. ${ }^{21}$ The

defendant does not know $v_{i}$ is not an insuperable barrier to waiver contracts of the sort described here being formed. For example, Lavie, 88 Notre Dame L Rev 697 (cited in note 6|, discusses strategies for securing waivers in which the potential nuisance source approaches various subgroups of nearby residents, whose prospective losses are roughly similar, in an effort to prevent the formation of a future litigation class.

${ }^{21}$ This should be contrasted with the claim that waivers will be adopted uniformly because they serve to shield corporations from lawsuits; see Myriam E. Gilles, Opting Out of Liability: The Forthcoming, Near-Total Demise of the Modern Class Action, 104 Mich L Rev 373 (2005). Of course, Gilles's argument is based on the assumption that waivers will be executed through take-it-or-leave-it (adhesion) contracts that do not permit any bargaining. Unsophisticated potential victims (for example, consumers) may sign such contracts without any sense of what they have done. My analysis is different, of course, because I am considering the actions of sophisticated potential victims. But even if a large number of potential victims are unsophisticated, the existence of a minority of sophisticated potential victims suggests that adhesion contracts will still leave room for the sophisticated parties to exit and seek other contracting parties. Any degree of competition should generate diversity in the set of contracts offered to potential victims. Contractual diversity should lead to efforts to sort potential victims into classes within which waivers may or may not be efficient. The waiver efficiency argument here is also inconsistent with the theory that waivers will target "stronger" prospective victims, see Lavie, 88 Notre Dame L Rev 697 (cited in note 6). Waivers should be observed within subclasses for which the deterrence benefit is small relative to the costs of litigation. Conversely, waivers will not be observed within subclasses for which the deterrence benefit is large relative to the cost of litigation. Stronger victims may sometimes be within the class for which the deterrence benefit exceeds the litigation cost, and if this is the case, waivers are unlikely to target such victims. 


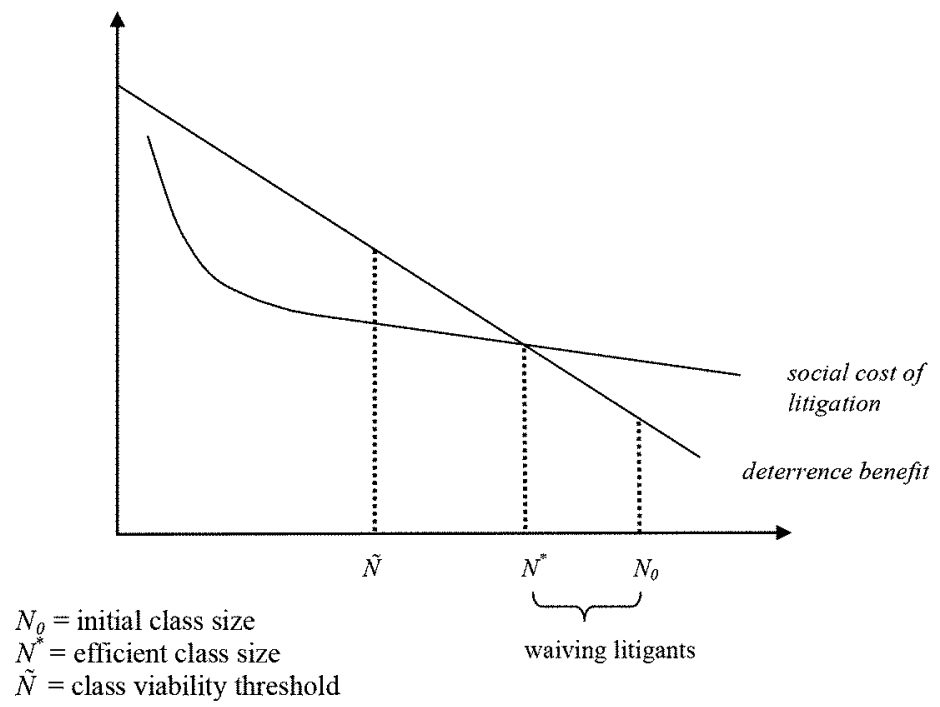

Figure 1. Class action waivers, efficient case.

deterrence benefit of class litigation is not sufficiently large for some class members to justify the litigation cost, and for those individuals, it would be socially (and privately) efficient if they executed a class action waiver, thereby saving the litigation costs. Put another way, the waiver setting described here is one where there is a subclass of potential victims within which the productivity of care is low in comparison to the expected costs of litigation. For victims within the subclass, a waiver permits them to take their compensation for risk up front, in the form of the price received for the waiver agreement, rather than seek compensation later through the class action.

One might find it a paradox that small prospective injuries are appropriate for waiver agreements, given that the class action device exists to enable small injuries to be aggregated and brought to court. But the ultimate matter of interest is the relation between deterrence benefit and expected litigation cost, not the injury amount. I have used the injury amount as a simple way of allowing for variation in the deterrence benefit. A more general approach would allow for variation in precaution's effect on the risk of injury, in the cost of precaution, and in the cost of litigation. Moreover, the result that optimality may require a subset of low-level prospective injuries to be waived indicates that it is incorrect as a general matter to suggest that an optimal litigation system would funnel all low-level injuries 
through the class action mechanism. If the deterrence benefit is low relative to the cost of litigation, waiver is appropriate, even for those low-level injuries that could be taken to court only through class action device. Because of the option to waive, made possible by the threat of class action, the victims of low-level injuries receive superior compensation than they would have obtained through litigation.

2. Inefficient Class Action Waivers. The foregoing discussion assumes that the class viability threshold is less than the efficient class size. Now suppose the viability threshold is greater than the efficient class size, as shown in Figure 2. Inefficient waivers are now possible, even in the absence of strategic bargaining tactics. Suppose the injurer is bargaining for a waiver with a victim at the class viability threshold. Since the efficient class size is below the viability threshold, the injurer's offer price for a waiver will exceed the asking price demanded by the victim..$^{22}$ The victim will waive and the threat of class action collapses, since the remaining number of victims will be less than the class viability threshold.

This result could be inefficient. The loss to society from taking away the class action right from the victims below the efficient class size could be greater than the gain from waiving the right for the victims above the viability threshold. For example, suppose the class viability threshold is 100 , the initial class size is 101 , and the efficient class size is 99 . The social cost of destroying the tort rights for 99 victims may easily be greater than the social gain from waiving the tort rights of victims 100 and 101. The key to the inefficiency is that a waiver by the victim at the viability threshold imposes external costs on all of the victims below the threshold. A waiver by the victim at the viability threshold effectively waives the class action rights of the remaining victims.

3. Strategic Bargaining and Inefficiency. The foregoing assumes that the parties bargaining over waivers consider only the joint costs and benefits associated with their contract, not the contract's effects on other parties. That is overly simplistic, though useful for identifying some of the basic implications of waiver agreements in the collective litigation setting.

\footnotetext{
${ }^{22}$ Note that nothing in this argument requires the potential injurer to know that he is bargaining with a potential victim located at the viability threshold. The fact that the waiver contract is efficient (because the bargaining takes place with victims located "above" the efficient class sizel is sufficient to guarantee that the waiver will be executed.
} 


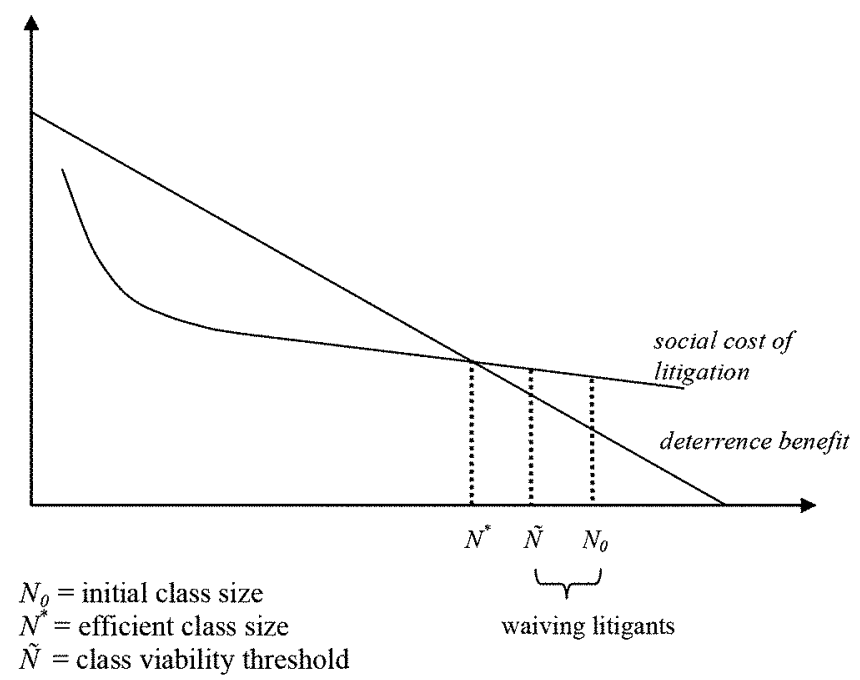

Figure 2. Class action waivers, possibly inefficient case.

If the injurer bargains strategically, the scope for inefficient waivers expands. ${ }^{23}$ The reason is that if the injurer is aware of the class viability threshold, he will have an incentive to offer a premium to victims above the threshold in order to push the class size below the threshold-in effect, bidding for sufficient waivers to preempt class litigation. ${ }^{24}$ The premium will reflect the savings to the injurer from destroying the class action right for all of the potential victims at one time.

To see the efficiency implications of strategic bargaining, suppose the initial class size is 105 , the efficient class size is 102 , and

${ }^{23}$ In the homogeneous victims case studied earlier, strategic bargaining could occur too. However, recall that in that setting, waivers will be efficient for all or efficient for none. Strategic considerations would arise only if there are informational asymmetries that could generate inefficient waivers for all of the potential victims.

${ }^{24}$ The incentive identified here has been explored, in different forms, in previous articles. Guttel and Leshem, 103 J Pub Econ at 55 (cited in note 6), study property buyouts that serve the roughly same effect as litigation waivers in the nuisance context. Che and Spier, 164 J Institutional \& Theoretical Econ at 4 (cited in note 13), examine divide-and-conquer strategies that a defendant can use, after the dispute arises, in litigation against a class of victims. Jennifer Arlen, Contracting over Liability: Medical Malpractice and the Cost of Choice, 158 U Pa L Rev 957 (2010), identifies a similar inefficiency in contracting for medical care. More general applications are discussed in Zvika Neeman, The Freedom to Contract and the Free Rider Problem, 15 J L Econ \& Org 685 (1999); Eric Bennett Rasmusen, J. Mark Ramseyer, and John Wiley, Naked Exclusion, 81 Am Econ Rev 1137 (1991). 
the class viability threshold is 100 . In the "nonstrategic" bargaining case, waiver agreements generate an efficient outcome in which low-deterrence-value victims waive and high-deterrence-value victims retain their rights, which optimizes the class action mechanism. For example, suppose the waiver price demanded by victims 103,104 , and 105 is $\$ 20$, and the waiver price demanded by victims 1 through 102 is $\$ 50$. Assume the amount the injurer is willing to pay is $\$ 25$ each for victims 103,104 , and 105 ; and $\$ 30$ each for victims 1 through 102. In the nonstrategic case, the injurer will secure waivers from victims 103,104, and 105, since his offer price exceeds the demand price of each. The injurer will not be able to secure waivers from victims 1 through 102, because the demand price of each victim exceeds the injurer's offer price. The class size of 102 provides the greatest deterrent benefit for every dollar devoted to class litigation.

If the injurer bargains strategically, knowing that the class viability threshold is 100 , he will offer a premium to victims 100 through 105 in order to get them to sign waiver agreements. The outcome would be one in which class litigation rights are effectively waived for all victims, reducing society's wealth. Since the injurer knows that 100 is the viability threshold, the value of waivers from victims 100 through 105 is greater than the amount that he would pay if he considered only the benefits of each deal, which is only $3 \times$ $\$ 20+3 \times \$ 30=\$ 150$. Taking the benefit of crossing the viability threshold into account, the value of waivers from 100 through 105 is $3 \times \$ 25+102 \times \$ 30=\$ 3135$. Thus, the injurer is willing to pay as much as $\$ 3135$, while victims 100 through 105 demand collectively only $3 \times \$ 30+3 \times \$ 50=\$ 240$ to waive their class litigation rights. If the injurer were to attempt to purchase each waiver at the demand price, he would have to pay a total of $102 \times \$ 50+3 \times \$ 20=\$ 5160$ for all of the waivers, which is far in excess of the total he would have been willing to pay, $\$ 3135$.

I have assumed that the victim does not bargain strategically. If, instead, the victim bargains strategically, then a victim located at or near the viability threshold could hold up the injurer for the entire value of the benefit the injurer would receive from preempting the class action. The inefficiency result could still occur, but it would be less likely. Return to the numerical example. If victims 100 through 105 bargain strategically-for their own interests and not as representatives of the entire group of victims-they could demand just a little less than $\$ 3135$ (the total benefit to the injurer) to sell their waivers collectively. The injurer might be willing to meet the price, but even then the trade would reduce social welfare. 
In any event, it seems reasonable to focus on the case in which only the injurer bargains strategically because the injurer is likely to be aware of the presence of a large pool of potential victims and the fact that it may be able to evade a class action through the use of waiver agreements. The case in which the victim bargains strategically is less plausible. One victim within a large pool of victims is unlikely to have any sense of how many waivers the injurer has secured already before he bargains with the injurer. And as the pool size expands, the likelihood of any particular victim being pivotal, in the sense of being located at the viability threshold, shrinks to zero. ${ }^{25}$ With a low probability of being pivotal, no rational victim would have an incentive to invest in determining whether he is at the viability threshold.

Including a substantial idiosyncratic component in the cost of litigation would not change this argument. Whatever the magnitude of the idiosyncratic issues, the class viability threshold has to be satisfied and a waiver signed by a victim located at the class viability threshold preempts class litigation. The distribution of the idiosyncratic component merely influences the potential pool of victims willing to initiate class litigation without changing the bargaining dynamics. ${ }^{26}$

4. Reconciling Strategic and Nontrategic Bargaining Cases. How should one reconcile the conclusions from the strategic and nonstrategic bargaining cases? The most plausible account is that the conclusions of the nonstrategic analysis should apply where the injurer is unable profitably to push the class size down below the viability

${ }^{25}$ Neeman, 15 J L Econ \& Org 685 (cited in note 24).

${ }_{26}$ Where there is a significant idiosyncratic component, the threat of class litigation by the $j$ th victim is credible only if $v_{j}>C_{p} / N+w_{p i^{\prime}}$ provided that the idiosyncratic proof component is observable. If the idiosyncratic proof component is not observable, then the claim is credible once the victim group size passes the viability threshold. If the victim group is below the viability threshold, no victim will have a credible claim. In the intermediate case where the idiosyncratic component is not observable, $v_{p}>C_{p} / N$, and $v_{i}<C_{p} / N+W_{p j}$ there may be a danger that class action lawyers will launch lawsuits that leave the victim class, or large parts of it, with zero or negative returns. For example, suppose there are three potential victims, each likely to suffer a loss of $\$ 10$. The cost of the common component is $\$ 20$. The cost of idiosyncratic proof is $\$ 0$ for the first one, and $\$ 20$ each for the remaining two. Suppose, too, that the cost of idiosyncratic component is unobservable ex ante. Since $\$ 10>\$ 20 / 3$, the class threat is credible. However, the total cost of litigation would be $\$ 40$, while the total compensation would be $\$ 30$. If a settlement required each party to bear its idiosyncratic cost in proving damages, the second and third victims would never seek compensation. 
threshold. This is more likely to be the case as the efficient class size increases, and as the price demanded to waive by the victims who are least inclined to waive increases. ${ }^{27}$

Return to the numerical example of the preceding part, and now assume that the initial class size is 600 (instead of the previous assumption of 105) and that the efficient class size is 400 . Again, the class viability threshold is 100 . In order to purchase enough waivers to push the class size below the viability threshold, the injurer will have to pay $200 \times \$ 20+301 \times \$ 50=\$ 19,050$. The benefit of doing so for the injurer is $200 \times \$ 25+400 \times \$ 30=\$ 17,000$. Since the benefit of eliminating the class action threat is less than the cost of pushing the class size below the viability threshold, the injurer will not attempt to do so.

When the nonstrategic bargaining assumptions are appropriate, this analysis delivers the following conclusions. In Scenario 3 (common litigation cost, idiosyncratic care), if the efficient class size is greater than the class viability threshold, class action waivers will be efficient, and indeed, waivers will be observed only when they are efficient. On the other hand, if the efficient class size is less than the class viability threshold, inefficient waivers may be observed.

When strategic bargaining is plausible-that is in settings where the injurer knows the class viability threshold and can preempt class litigation by pushing the class size below the viability levelthe case for inefficiency resulting from class waivers is considerably stronger. If the efficient class size is substantially greater than the viability threshold, efficiency is still likely to result. But when the efficient class size is near the viability threshold, and bargaining is strategic, inefficient waiver agreements may be observed whether the viability threshold is above or below the efficient class size.

\section{E. Class Action Waivers in Common Care Setting}

A central feature of many class actions is the existence of a common element in the cost of taking care (Scenario 4). Take the case where the class of victims consists of customers of a financial institution that regularly skims off a small amount of money from their accounts through a method that is difficult to detect and to prove in litigation. The proof of fraud against the institution is the same for

${ }^{27}$ Let $\beta_{H}$ and $\beta_{L}$ be the offer prices for the two types of victim, and let $\alpha_{H}$ and $\alpha_{L}$ be their respective demand prices, where $\beta_{L}>\alpha_{L}$ and $\beta_{H}<\alpha_{H}$. The cost of getting just enough waivers to push the class below viability will exceed the benefit when $N^{*}\left(\alpha_{H}-\right.$ $\left.\beta_{H}\right)>\left(N-N^{*}\right)\left(\beta_{L}-\alpha_{L}\right)+(\tilde{N}-1) \alpha_{H^{*}}$ See the Appendix. 
every member of the class of victims, with no idiosyncratic variation at all.

Consider the social desirability of litigation in this setting. If there is no threat of litigation, and the injurer (therefore) does not take care, the total social cost will equal the aggregate harm in the absence of injurer care, $N p v$. If the class action threat exists, the total social cost will equal the sum of aggregate harm and litigation costs, given injurer care, and the cost of common care: $N q v+q \mid c_{p N}+$ $c_{d N} l+X$. Litigation is socially desirable when the deterrence benefit, $N(p-q) v-X$, is greater than the cost of litigation, $q\left(c_{p N}+c_{d N}\right)$. If only the common component of litigation proof matters, $c_{p N}=C_{p}$ and $c_{d N}=$ $C_{d}$. Thus, on a per victim basis, litigation is socially desirable when $(p-q) v-X / N>q\left(C_{p} / N+C_{d} / N\right)$.

Suppose the class size is above the viability threshold. A waiver by a victim would not change his likelihood of being injured, since the injurer would be induced to maintain care given the threat of class action from the remaining victims. A waiver prevents the victim from receiving compensation after an injury and relieves the victim of his share of the litigation expense; thus, the minimum price the victim will set for a waiver is $q V-q C_{p} / N$. The injurer, by purchasing a waiver, does not avoid the burden of taking care for the entire class; he avoids only the cost of compensating the victim and the share of litigation defense costs attributable to the victim: $q v+$ $q C_{d} / N$. Since the injurer's offer price definitely exceeds the victim's asking price, a waiver will be exchanged.

Suppose class size is below the viability threshold. The threat of a class action is zero, so the injurer does not take care. The victim would willingly waive his right for any payment in this setting, because it is worthless. The injurer would have no reason to purchase it, other than to avoid uncertainties over the location of the class viability threshold.

The question of interest is what happens at the class viability threshold $(N=\tilde{N})$. For the victim at the threshold-the pivotal victim-waiving his right to sue increases his likelihood of injury, so his asking price will reflect this change in prospects: $p v-q\left(C_{p} / \tilde{N}\right)$. The injurer, by securing a waiver, avoids the cost of common care as well as the litigation costs and liability for the entire class: $X+$ $q \tilde{N} v+q C_{d}$. A waiver will be mutually beneficial, as between the injurer and the pivotal victim, when $p v-q\left(C_{p} / \tilde{N}\right)<X+q \tilde{N} V+q C_{d}$. Recall that class litigation is socially desirable when $(p-q) v-X \mid N>$ $\left.q \mid C_{p} / N+C_{d} / N\right)$, where $N$ is the size of the entire pool of victims. Given the potentially large differential between the injurer's offer price and pivotal victim's asking price, the class action is likely to be waived by all victims, through a process of one-by-one contracts, 
even when retention of the class litigation right would be socially desirable..$^{28}$

This inefficiency result assumes that the victim at the viability threshold knows that his decision is pivotal and bargains for a price that compensates him for the costs that he would suffer as a result of signing a waiver. However, as the size of the class increases, the assumption that the victim knows that he is pivotal becomes less plausible. ${ }^{29}$ If the victim sitting at the viability threshold is unaware of his position, the inefficiency result is probably more likely to be observed.

The incentive divergence problem could be avoided if the litigation rights of the class were transferred to a third party, who would then negotiate, in the manner of a union bargaining agent, over the terms of a class litigation waiver. A single owner would internalize all of the losses to infrapivotal victims when negotiating over a class action waiver at the class viability threshold. A variation on the single-owner solution is coordinated bargaining among the potential victims. If the victims can communicate with each other over the terms of the waiver, they would act as a single entity in setting a price for the entire bundle of waivers.

\section{POSITIVE-EXPECTED-VALUE CLASS ACTIONS}

The model examined previously assumes each victim's loss is less than the cost of the common component of litigation proof. However, the incentive problems explored there remain even when the victim's loss is greater than the common litigation cost component. The reason is that the common litigation cost component gives victims an incentive to free ride on the litigation efforts of the first plaintiff.

When $v>C_{p}$, the first victim to sue would enjoy a positive payoff from his lawsuit. However, the second victim to sue would enjoy a greater payoff because he would avoid the common litigation cost component-he receives the payoff $v$ rather than $v-C_{p}$. If we imag-

\footnotetext{
${ }^{28}$ Sequential property buyouts that operate in effect as waivers are explored in Guttel and Leshem, 103 J Pub Econ at 55 (cited in note 6), and Lavie, 88 Notre Dame L Rev 697 (cited in note 6), discusses predispute waivers that target prospective victims who are likely to sue or to receive high damages, leaving only victims who are less likely to sue or with low damages as potential litigants. The sequential stripping of rights (after harm has occurred) is explored in Che and Spier, $164 \mathrm{~J}$ Institutional \& Theoretical Econ 4 (cited in note 13).

${ }^{29}$ Neeman, 15 J L Econ \& Org 685 (cited in note 24).
} 
Table 2. Payoffs from Litigation, $v>C_{p}$.

\begin{tabular}{|c|c|c|c|}
\hline & & Victim B & \\
\hline \multirow{3}{*}{ Victim A } & & Sue Immediately & Wait \\
\hline & Sue Immediately & $V-C_{p}, V-C_{p}$ & $V-C_{p}, V$ \\
\hline & Wait & $V, v-C_{p}$ & 0,0 \\
\hline
\end{tabular}

ine two victims, with a choice of two pure strategies, "Sue Immediately" and "Wait," the following payoff structure materializes:

The final cell of the payoff table shows both victims receiving zero because they fail to bring suit (for example, the decision to wait puts them beyond the statute of limitations). Under this payoff structure, the two off-diagonal outcomes (one chooses "Sue Immediately" and the other chooses "Wait") are Nash equilibria in pure strategies.

The two off-diagonal outcomes raise interpretive difficulties because they require one victim to sue immediately while the other one waits, and the victim who waits does better than the one who sues immediately. If either victim could commit to waiting, he could guarantee himself a higher payoff than the one who sues. A more intuitively appealing result can be found by solving for the mixed strategy equilibrium. Think of the pool of victims as composed of some who are likely to sue immediately (quick-suit victims) and others who are likely to wait (slow-suit victims). The decisions of victims will be determined by their lawyers, so the financial return from being in either category will be the primary determinant of the proportions of each to the whole. So that the long-run payoff from being in either category is the same, the expected value of suing immediately, given the proportion of quick-suit victims in the population, must be equal to the expected value of waiting. ${ }^{30}$ Thus if $a^{*}$ is the long-run equilibrium proportion of quick-suit victims, the equilibrium value equates the expected value of waiting, $a v$, with the payoff from suing immediately, $v-C_{p^{\prime}}$ which implies $a^{*}=\left(v-C_{p}\right) / v$. Thus, in the absence of the class action device, a portion of the pool of victims, $\left(1-a^{*}\right)^{2}$, will fail to bring suit because of the strategic incentives created by the common litigation cost component.

${ }^{30}$ If the payoffs were not the same, all lawyers would either sue immediately, or all lawyers would wait. But if all plaintiff-side lawyers waited, the payoff to suing immediately would be greater than that for waiting. Similarly, if all plaintiff-side lawyers sued immediately, a lawyer could gain by waiting. 
The free rider problem results in an equilibrium in which a substantial percentage of victims fail to assert their legal rights, even though they have injury claims that exceed the cost of the common component of litigation. The existence of a common component of proof provides an incentive to victims to wait and let some other victim be the first to prove the common component, in the hope of sauntering into court later to collect damages at much lower expense. This incentive to free ride distorts litigation even when there are substantial idiosyncratic issues in the litigation. Many of the victims who wait may reduce the value of or effectively forfeit their legal rights. ${ }^{31}$ Given that some victims fail to assert their claims, the injurer may not be forced to pay in full for the losses caused by his conduct. If the shortfall in damages is large enough, the injurer will not have an incentive to take socially desirable care.

Here, the justification for the class action is not that it makes the assertion of legal claims economical, but that it avoids the outcome in which the free rider incentive among victims generates an equilibrium in which injurers adopt socially inadequate care. ${ }^{32}$ The mere existence of a substantial common component of litigation proof justifies resort to the class action device.

Does the free rider problem have implications for the welfare consequences of class action waivers? The answer is yes; inefficient waivers can occur in the positive-expected-value setting, just as in the negative-expected value setting. Suppose that among the pool

${ }^{31}$ Admittedly, this is an exaggerated view. A rational victim will know that if he waits too long, he may forfeit his right, and therefore will not wait too long. Moreover, the lawyer representing the first victim to sue may not be willing to share his research with later lawyers. In addition, federal courts do not permit litigants who simply wait, to reduce their costs, to take advantage of offensive issue preclusion, see Parklane Hosiery Co v Shore, 439 US 322 (1979). All of this suggests that the strategy of waiting (free riding), in order to reduce litigation expenses, is both more risky than suggested in the stylized analysis in the text and unlikely to be adopted without a serious examination of the risks. Still, the strategy of waiting is likely to have a positive payoff, given the high likelihood that some valuable information will be gleaned by watching the experience of the first lawyers to sue. The optimal waiting time may be difficult to calculate, and is likely to involve some risk of degrading the value of the right to sue. This should be sufficient to support the model's depiction of incentives in the class litigation game.

${ }^{32}$ This "free riding" theory offered here should be distinguished from an alternative theory supporting the use of class actions in the positive-expected-value setting presented by Kathyn E. Spier and David Rosenberg, On Structural Bias in the Litigation of Common Question Claims, Harvard Public Law Working Paper No 11-28 (October 14, 2011), online at: http://ssrn.com/abstract=1950196 (last visited Nov 17, 2015). In the Spier-Rosenberg account, individual plaintiffs have weak incentives to invest in the prosecution of the case in comparison to defendants. If plaintiffs invest too little, they will lose at trial, and their losses will reduce the deterrent effect of the law. 
of victims, a critical percentage must be inclined to sue immediately (rather than free ride) in order to provide the injurer with an incentive to take care. In other words, if the percentage of quick-suit victims falls below the hypothesized critical level, the injurer stops taking care. If all victims waive their class action rights, and retain only the right to sue individually, then the resulting equilibrium percentage of quick-suit victims could fall below the hypothesized critical level. Thus, a prohibition on waivers could enhance welfare by precluding an outcome in which the injurer rationally refuses to take care.

\section{APPLICATIONS}

The main lesson of this framework is that the scope for inefficient waiver agreements, among informed agents, is considerably broader in the class action setting than in the standard one-on-one litigation scenario. Inefficient waivers of class action rights are a plausible and indeed probable occurrence. However, waivers can also enhance the efficiency of the litigation system. In particular, when the efficient class size is so large that the defendant is unlikely to be able to secure enough waivers to preempt class litigation (by pushing the class size below viability), waivers will tend to maximize the deterrence benefit per dollar invested in litigation.

Although my focus has been on class action waivers, this framework has broader applications to the literature on class actions, including the waiver of statutory litigation rights, waiver through arbitration agreements, and the scope of class litigation.

\section{A. Factors Driving Waivers}

This model shows that the factors driving class litigation waivers are the same as those driving waivers of ordinary litigation: low productivity of precaution, high cost of taking care, and high expected litigation costs. Two features appear to distinguish class actions from ordinary litigation. First, the class action appears to magnify the expected cost of litigation - that is, it makes litigation more costly and more frequent. Second, the incentives that generate class claims can also generate an expansion of claiming into areas where the deterrence value of litigation is minimal.

Because the class action device permits claims to be aggregated into much larger damages than ordinarily observed in litigation, litigation costs rise along with the size of the claims. ${ }^{33}$ Large claims

\footnotetext{
${ }^{33}$ Ulen, 32 Eur J L \& Econ at 185 (cited in note 8)
} 
induce parties to invest more into litigation. ${ }^{34}$ A plaintiff who thinks he can increase his expected judgment by $\$ 1000$ will invest an additional $\$ 900$ into his case in order to do so.

The prospect of large awards generates a high likelihood of settlement, which spurs still more litigation and drives up expected litigation costs. Firms are likely to settle because the size of the claim pushes them into a range of risks in which even large firms are risk-averse..$^{35}$ For example, suppose the damage claim for the class is $\$ 10$ billion dollars and there is a one percent chance of an erroneous judgment for the plaintiff. Under these conditions, risk-neutral defendants, will offer settlements on the order of $\$ 100$ million, and risk-averse defendants will offer considerably more.

The high likelihood of settlement, in turn, generates incentives for plaintiffs to assert novel and sometimes dubious claims. Many claims of false advertising appear to be based on this incentive structure. ${ }^{36}$ In addition, plaintiffs have incentives to inflate the size of the class by including fraudulent victims.

The high likelihood of settlement, coupled with the relatively unregulated nature of settlements, generates incentives for collusive deals, further encouraging litigation and driving up litigation costs. Observed settlements have often entailed small benefits for the victim class-such as vouchers to purchase more of the defendant's products - coupled with large payouts for lawyers. The settlements are consistent with an incentive on the part of both injurer's and plaintiffs' lawyers to extinguish class claims in exchange for a side payment to the lawyers - "sweetheart settlements" $\left(.{ }^{37}\right.$ For the same reason plaintiffs' lawyers seek settlements that set aside large

\footnotetext{
${ }^{34}$ If the probability of a judgment for either party is a function of expenditures, large claims will induce additional spending. The additional spending might, if the probability of a verdict for either party is dependent on litigation expenditures, bias the trial results in favor the party that spends the most, which will be the defendant if a class is not certified, see Spier and Rosenberg, On Structural Bias in the Litigation of Common Question Claims (cited in note 32).

${ }^{35}$ Judge Posner famously rejected a class certification bid on this basis in In re Rhone-Poulenc Rorer, Inc, 51 F3d 1293 (7th Cir 1995).

${ }^{36}$ See, for example, Thorogood v Sears, Roebuck e) Co, 547 F3d 742 (7th Cir 2008) (Posner expressing skeptical view of consumer deception claim).

${ }^{37}$ Susan P. Koniak and George M. Cohen, Under Cloak of Settlement, $82 \mathrm{Va} \mathrm{L}$ Rev 1051 (1996); Bruce L. Hay and David Rosenberg, "Sweetheart" and "Blackmail" Settlements in Class Actions: Reality and Remedy, 75 Notre Dame L Rev 1377 (2000). In contrast the "sweetheart settlements" view suggests that many forms of nonpecuniary settlement may be efficient; Geoffrey P. Miller and Lori Singer, Nonpecuniary Class Action Settlements, 60 Law \& Contemp Probs 97 (1997).
} 
sums for third parties, such as special interest groups, in a process known as the cy pres settlement. ${ }^{38}$

Sweetheart and cy pres settlements in class litigation imply that the deterrence benefit from litigation is likely to be less than its cost. The reason is straightforward: if plaintiffs' lawyers sue in part to transfer wealth, then the deterrence goal presumably takes a lesser priority among the factors motivating litigation. ${ }^{39}$ In addition, expected litigation costs are likely to be driven up as interest groups press plaintiffs' lawyers to file suits that can be settled in order to provide payouts to the very interest groups that urge class action litigation.

These factors, individually or combined, work to make class litigation waiver agreements efficient in probably more settings than suggested by the formal model of this paper. When the deterrence value sinks sufficiently low relative to the costs of litigation, competitive pressure will drive firms to seek waivers. Sophisticated buyers or sellers who choose to waive their class litigation rights do so because the benefits they receive in exchange, in the form of a reduced price or in the availability of the good or service, are more valuable to them than the litigation right.

\section{B. Arbitration of Claims}

The contract between the injurer and the victim may require oneon-one arbitration of a claim rather than a waiver of the right to sue. Does the presence of an arbitration clause, instead of a waiver clause, substantially alter the foregoing analysis?

The economics of predispute arbitration contracts are not substantially different from the economics of waiver agreements. ${ }^{40}$ For both types of agreement, the social desirability condition is the same. The agreement benefits the contracting parties, and society as well

${ }^{38}$ On such settlements, Sam Yospe, Cy Pres Distributions in Class Action Settlements, 2009 Colum Bus L Rev1014 (2009); Martin H. Redish, Peter Julian, and Samantha Zyontz, Cy Pres Relief and the Pathologies of the Modern Class Action: A Normative and Empirical Analysis, 62 Fla L Rev 617 (2010).

${ }^{39}$ More generally, the deterrence value of class litigation declines because of agency costs; see Jonathan R. Macey and Geoffrey P. Miller, The Plaintiffs' Attorney's Role in Class Action and Derivative Litigation: Economic Analysis and Recommendations for Reform, 58 U Chi L Rev 1 (1991). The model presented here could be modified to incorporate agency costs, in order to show that agency costs reduce the deterrence benefit from class litigation.

${ }^{40}$ Hylton, 8 Sup Ct Econ Rev at 209 (cited in note 4). 
unless there are negative externalities, if the deterrence benefits forgone are less than the litigation costs avoided.

In the case of a waiver, it is straightforward to see how the social desirability criterion operates. A waiver agreement discards the threat of litigation, and for that reason dilutes the deterrent threat of litigation. On the other hand, the waiver saves litigation costs. Where the forgone deterrence benefits are small, and the litigation costs avoided are large, waivers enhance society's welfare.

Arbitration requires a slightly different calculus. An agreement to commit future disputes to an arbitration forum may or may not reduce deterrence. If the arbitration forum has superior accuracy properties than the typical court, committing to arbitration may enhance deterrence. The reason is that a more accurate forum will punish the guilty and exonerate the innocent with higher likelihood. Such a system creates a wider gap between the payoffs for legal compliance and legal noncompliance, which enhances incentives to comply with the law. This is likely to be observed when the arbitration forum has greater expertise than does the typical court in resolving a particular type of dispute. For example, an arbitration forum consisting of medical experts might provide a more accurate assessment of malpractice claims than would the typical jury.

A decision to commit a dispute to arbitration may or may not reduce dispute-resolution costs. An arbitration forum consisting of experts who are paid at market rates to decide disputes may be more costly than a court consisting of ordinary jurors.

Given these considerations, an arbitration contract might be efficient even when litigation costs are higher in the arbitration forum than in the typical court. The reason is that the enhanced deterrence benefits from arbitration may offset the higher litigation costs. Conversely, an arbitration contract might be efficient even when the deterrence benefits are lower under arbitration-say, because the arbitration forum is less expert than the court-because the litigation costs are substantially lower in the arbitration forum than in court.

In the main class litigation setting (Scenarios 3 and 4), where a claim would be unprofitable to one victim because of the expensive common component of litigation cost, a predispute agreement committing the victim to bring an individual claim in arbitration could be equivalent to a waiver. However, the ultimate conclusion depends on the details of the contract. If the injurer agrees to a special litigation cost allocation rule, such as the pro-plaintiff fee shifting (including expert fees), a commitment to individualized arbitration would not be equivalent to a waiver; the victim could bring his claim and shift the common litigation cost component to the 
injurer. ${ }^{41}$ If the injurer does not agree to a special litigation cost allocation rule, then an agreement to bring only individual claims in arbitration could be equivalent to a waiver. ${ }^{42}$

In the end, concluding that an agreement to arbitrate on an individual basis is equivalent to a waiver merely returns us to the analysis of the preceding parts. The fact that such an agreement might operate as a waiver leaves open the question whether the waiver is efficient. In the Scenario 3 setting where the precaution decision is idiosyncratic and the class viability threshold is considerably less than the efficient class size, arbitration agreements that operate in effect as waivers may be efficient. In the scenario in which the precaution cost is centralized for the entire class of victims, efficient waiver contracts seem unlikely. These considerations can be applied to special cases, such as antitrust.

\section{Waiver of Antitrust Rights}

Should potential antitrust plaintiffs be permitted to waive their rights under the antitrust laws? In this framework, this question boils down to examining which of the litigation scenarios examined above best describes antitrust.

Start with the structure of litigation costs. Is antitrust a setting where there is a common proof element for all plaintiffs, or one where litigation proof is primarily idiosyncratic? In the typical pricefixing scenario, antitrust is clearly a setting where there is a common proof element for all victims. The consumer-victims of a price-fixing scheme form a class, often with economic losses that are relatively small in comparison to the cost of proving an antitrust violation (for example, the costs of investigation and procuring evidencel. Proof that the defendant engaged in price-fixing typically settles the liability question for all members of the class of consumers.

However, the common proof structure is an accurate description of only one category of antitrust claims-involving price-fixing or

${ }^{41}$ For example, the arbitration contract in Concepcion permitted plaintiffs to shift attorneys' fees and expert fees for nonfrivolous claims to AT\&T. See ATET Mobility $v$ Concepcion, $131 \mathrm{~S}$ Ct 1740, 1744 (2011). In addition, if the arbitration contract permits lawyers to share the cost of the common component of litigation, the individualized arbitration agreement need not preclude claims.

${ }^{42}$ But this depends entirely on the ability of lawyers to share costs within a portfolio of cases. A lawyer might have an incentive to pay for an expensive expert if he can use the same expert's report in many arbitration cases. On strategies for sharing costs among numerous arbitrations, see Myriam Gilles and Anthony Sebok, Crowd-Classing Individual Arbitrations in a Post-Class Action Era, 63 DePaul L Rev 447 (2014). 
market allocation schemes that directly harm consumers. Monopolization claims, in contrast, are typically brought by a firm on the theory that it has been excluded from the market by a dominant rival. For example, a plaintiff firm may sue because the defendant refused to deal with it. The basis for the lawsuit is a theory that the exclusionary act imposes a derivative injury on consumers by limiting competition and thereby causing an increase in prices, but the evidence of consumer harm is often ambiguous. These cases are better viewed as falling within the standard one-on-one litigation scenario (Scenario 1), in which waivers of litigation rights among sophisticated parties generally enhance society's welfare.

It follows that a rule barring enforcement of waivers of litigation rights in antitrust would be too broad to be justified on social welfare grounds. ${ }^{43}$ This framework does not provide a justification for refusing to enforce waivers of all antitrust claims, especially monopolization claims. However, the case for refusing to enforce waivers of price-fixing claims is more complicated.

Price-fixing litigation falls within the Scenario 3 and Scenario 4 settings, where litigation waivers might be inefficient. The Scenario 3 setting is where the forbearance decision is idiosyncratic; Scenario 4 where there is a centralized forbearance decision taken for the class of victims as a whole. The classic price-fixing case falls in Scenario 4: a firm makes one centralized forbearance decision, whether to set its price at the cartel level, and this decision imposes an injury on all members of the class. This is the setting in which the case for prohibiting waivers of class litigation rights is strongest.

However, a prohibition on the enforcement of waivers governing price-fixing claims may not be socially desirable, even though private and social incentives to waive diverge. Invalidating waivers may or may not enhance social welfare, depending on the circumstances. If the waiver contract allows for arbitration, with shifting of all costs (including expert fees), then it is unlikely to thwart private antitrust enforcement. ${ }^{44}$ In addition, with the option of public enforcement of antitrust, the existence of a class viability threshold is of doubtful importance. Potential victims of price-fixing could all waive their

${ }^{43}$ The rule was adopted by the Second Circuit in In Re American Express Merchants' Litigation, 667 F3d 204 (2012), and reversed in American Express Co V Italian Colors Restaurant, 570 US _ (2013).

${ }^{44}$ Relatedly, David L. Noll, Rethinking Anti-Aggregation Doctrine, 88 Notre Dame L Rev 649 (2012), proposes that class action waivers not be enforced where they would result in "substantial wrongdoing." Where public enforcement remains vigorous, it seems unlikely that class action waivers will meet the substantial wrongdoing requirement. In general, however, the definition of "substantial wrongdoing" and the welfare effects of Noll proposal are unclear. 
rights, and yet the pressure to comply with the law would remain as long as the threat of public enforcement is significant.

A refusal to enforce a waiver agreement governing price-fixing claims might be justified under a set of narrower conditions: where there is no effective public enforcement backstop, where the potential victims are too numerous to coordinate in bargaining, and where the arbitration agreement (which operates in effect as a waiver) does not permit claimants to shift all litigation costs to the defendant. For example, in the context of goods marketed to ordinary consumers, the typical consumer may be too uninformed and have too little influence over the actions of government enforcement agencies to present a serious threat of initiating a public enforcement action against an antitrust violator; and consumers as a group are likely to be too numerous to coordinate in bargaining. Under these conditions, the danger that waiver agreements will reduce society's welfare is significant. ${ }^{45}$

\section{Scope of Class Actions}

Real cases are mostly a mixture of the stylized scenarios introduced in Table 1. The plaintiff's case often will involve a mixture of common and idiosyncratic components of proof. The injurer's precaution will also involve common and idiosyncratic components. The most difficult issue in many litigated cases is determining whether the evidence supports the claim that a case consisting of numerous victims deserves to be certified as a class action.

Under the framework of this Article, a substantial common component of proof should be sufficient to meet the minimal requirement for class action status, even if there are idiosyncratic issues as well. The mere fact that there are idiosyncratic issues should not deprive a victim group of class action status as long as there is a substantial common component of proof. ${ }^{46}$

${ }^{45}$ The dire predictions of Gilles, 104 Mich L Rev 373 (cited in note 21 ), are based on this scenario. However, there are other scenarios which waiver contracts will be offered to sophisticated contracting parties. A regulatory policy governing the enforceability of class action waiver contracts should take into account the likely sophistication of the parties and the potential for welfare-reducing contracts.

46 One argument to the contrary is that when the idiosyncratic issues are substantial, there is little guarantee that the incentives of class attorneys and victims are aligned. Attorneys may file suit, settle, and leave most of the class with a zero or negative return. But this seems to point to a need for reforms that help to align incentives rather than decertification, see generally Hay and Rosenberg, 75 Notre Dame L Rev 1377 (cited in note 37). In the absence of any plausible reforms decertification is a second-best approach to regulating attorney incentives when the idiosyncratic issues are substantial. 
An argument to the contrary is that when the idiosyncratic issues are substantial, there is little to guarantee that the incentives of class attorneys and victims are aligned. Attorneys may file suit, settle, and leave most of the class with a zero or negative return. ${ }^{47}$ But this points to a need for reforms that help to align incentives rather than decertification. In the absence of plausible reforms decertification is a second-best approach to regulating attorney incentives when the idiosyncratic issues are substantial.

Federal Rule of Civil Procedure 23(a) requires proposed class actions to satisfy requirements of numerosity, commonality, typicality, and adequacy of representation. Rule 23(b)(3), governing actions for damages, holds that class action status is inappropriate if the common issues do not predominate over idiosyncratic issues. These are not easy standards to apply, and the $23(\mathrm{~b})(3)$ requirement appears to go against the simple economic message that the mere existence of a substantial common component of proof can justify class action status.

The plaintiffs in Wal-Mart v Dukes, a 23(a) "commonality" case, claimed that female employees were denied promotions and raises in accordance with a general firm policy of discrimination. However, the policy's implementation depended on the actions of thousands of low-level managers. The Supreme Court rejected the bid to certify a class of 1.5 million victims.

Under the plaintiffs' theory of the case, Wal-Mart falls under Scenario 3 (common litigation proof component, idiosyncratic care), in which the common component of litigation proof predominates over idiosyncratic issues. To prove their theory, the plaintiffs needed data on firm-wide promotion practices, which are expensive to collect and analyze, and this constituted the common component of litigation proof indicated by the plaintiffs' theory. In addition, each of the 1.5 million victims, to the extent they had suffered discrimination, had suffered it in a unique way. Thus, each victim's claim involved some idiosyncratic proof of discrimination.

In rejecting the plaintiff's bid for class certification, the Court held, in effect, that there was only weak support for the theory that Wal-Mart was a Scenario 3 case, because the evidence of a centralized discriminatory policy was speculative. In terms of this paper's framework, Wal-Mart, as seen by the Court, involved substantial idiosyncratic proof questions and a trivial or nonexistent question of common proof. The balance between common and idiosyncratic parts is less important than the fact that the common component did not appear to be substantial.

\footnotetext{
${ }^{47}$ See the example cited in note 20.
} 
Antitrust cases brought by purchasers seeking compensation for overcharges under Rule 23(b)(3) typically fall in the Scenario 3 (common litigation cost) or Scenario 4 (common litigation cost and common or centralized care) categories in which class actions may be necessary for injury claims to be asserted. A class of antitrust victims generally will consist of injury claims that have a common component of proof; specifically, the antitrust violation. Still, the Supreme Court rejected certification in Comcast Corp v Behrend, ${ }^{48}$ an antitrust case. Class certification had been granted on only one of four antitrust theories that the plaintiff had initially asserted. However, the plaintiff's evidence did not show that the consumers within the proposed class had suffered any harm under the theory on which certification had been based. The Court held that idiosyncratic claims dominated common claims.

Although the Court's view is at first glance inconsistent with the framework of this paper, it can be defended on the ground that to the extent harm had been demonstrated, it resulted from a combination of the four antitrust theories, and therefore any recovery for the class would have to be understood as recovery under all of the antitrust theories, including those rejected as unsuitable for class certification. However, the core flaw in the plaintiff's case was not that the consumer class's harms did not involve a common component of litigation proof, but the lack of sufficient evidence of consumer harm under the theory on which certification had been granted. The imposition of a requirement for such evidence is consistent with treating $23(\mathrm{~b})(3)$ as a proof standard, requiring the case to have a common proof element that is likely to be satisfied by the plaintiff.

\section{CONCLUDING REMARKS}

The welfare economics of waivers in the class action setting are more complicated than in the standard, one-on-one litigation scenario. In the standard litigation scenario, waivers between informed agents enhance society's welfare, because they are exchanged when and only when the deterrence value of litigation is less than its cost. In the class litigation scenario, in contrast, waivers between informed agents might be exchanged even though they reduce society's wealth. The simple reason is that there is a pivotal prospective victim, sitting at the class viability threshold, who effectively waives the rights of the entire class. But the possibility of an inefficient outcome is not enough by itself to justify a blanket

\footnotetext{
${ }^{48}$ Comcast Corp v Behrend, 133 S Ct 24 (2013).
} 
nonenforcement policy with respect to waivers of class litigation rights. A regulatory policy against enforcing waiver agreements, to have any prospect of raising social welfare, would have to target the settings in which waivers are likely to be inefficient. And even in the scenarios in which waivers are potentially inefficient there are special circumstances which counsel caution toward proposals to prohibit such agreements. The welfare consequences of waivers depend, inevitably, on the terms of the agreement and the regulatory environment in which the contracting parties are situated.

\section{APPENDIX: PREEMPTION OF CLASS ACTIONS THROUGH WAIVER AGREEMENTS}

This appendix provides a more formal version of the argument in the text. Suppose there are two types of victim with damage levels $V_{H}$ and $V_{L^{\prime}}$ representing high damages and low damages, respectively. Let $\alpha_{H}$ and $\alpha_{L}$ be the demand prices for waivers of the two types of victim, which means $\alpha_{H}=p V_{H}-q C_{p} / N$ and $\alpha_{H}=p V_{L}-q C_{p} / N$. Let $\beta_{H}$ and $\beta_{L}$ be the offer prices for waivers from injurers to the two types of victim, which means $\beta_{H}=X+q V_{H}+q C_{d} / N$ and $\beta_{L}=X+q V_{L}+$ $q C_{d} / N$. In addition, let $\beta_{L}>\alpha_{L}$ and $\beta_{H}<\alpha_{H}$, which means that waivers are efficient for the low-damage victims and inefficient for the highdamage victims. The initial class size is $N_{0}$, the efficient class size is $N^{*}$, and the viability threshold is $\tilde{N}$.

\section{A. Nonstrategic (No Preemption) Bargaining}

The injurer is assumed here to negotiate waiver agreements, one on one, without attempting to preempt the class. Assume, first, that $N^{*}>\tilde{N}$. Retention of the class action right by all members of the class is socially desirable if

$$
\left(N_{o}-N^{*}\right)\left(\alpha_{L}-\beta_{L}\right)+N^{*}\left(\alpha_{H}-\beta_{H}\right)>0,
$$

where $\left(N_{0}-N^{*}\right)$ is the number of potential victims for whom the deterrence benefit is less than the expected cost of class litigation. Since the first term is negative, waiver contracts enhance social welfare by canceling the class litigation right for the victims in the group $N_{0}-N^{*}$. If $N^{*}<\tilde{N}$, the parties in the group $N_{0}-(\tilde{N}+1)$ will efficiently waive their litigation rights, and the class is effectively preempted. Waiver (or preemption) of the entire class is efficient if

$$
\left(N_{0}-\tilde{N}-1\right)\left(\beta_{L}-\alpha_{L}\right)>\left[(\tilde{N}-1)-\left(N^{*}+1\right)\right]\left(\alpha_{L}-\beta_{L}\right)+N^{*}\left(\alpha_{H}-\beta_{H}\right),
$$

which means that the social gain from waiving the class litigation right for the first set of victims, $N_{0}-\tilde{N}-1$, exceeds the social loss 
from preempting the class litigation rights of the second set of victims. This condition may or may not hold.

\section{B. Strategic Bargaining and Preemption of Class Litigation}

Now the injurer bids preemptively to cancel the class litigation right. Assuming $N^{*}>\tilde{N}$, the amount that the injurer is willing to bid for a sufficient number of waivers to eliminate the class action threat is

$$
\text { Iniurer preemptive bid }=\left(N_{0}-N^{*}\right) \alpha_{L}+\left(N^{*}-\tilde{N}+1\right) \alpha_{H} \text {. }
$$

Victims in the group $\left(N_{O}-N^{*}\right)$ are those for whom waiver is efficient. In order to completely eliminate the threat of a class action the injurer must also obtain waivers from the remaining victims up to and including the victim located at the class viability threshold. Thus, if the class size is 600 , the efficient class size is 300 , and the class viability threshold is 100 , the injurer will offer a relatively low bid for the 300 low-damage victims, a relatively high bid for the victims between (and including) victims number 300 and 100 .

The benefit the injurer receives from securing enough waivers to eliminate the class action threat is

$$
\text { Injurer preemptive benefit }=\left(N_{0}-N^{*}\right) \beta_{L}+N^{*} \beta_{H} \text {. }
$$

The injurer will offer a preemptive bid whenever the cost of the preemptive bid is less than the benefit to the injurer. This condition is satisfied when $N^{*}\left(\alpha_{H}-\beta_{H}\right)<\left(N_{0}-N^{*}\right)\left(\beta_{L}-\alpha_{L}\right)+(\tilde{N}-1) \alpha_{H^{\prime}}$ or equivalently, when

$$
\alpha_{H}-\beta_{H}<\left(N_{o} / N^{*}-1\right)\left(\beta_{L}-\alpha_{L}\right)+\left((\tilde{N}-1) / N^{*}\right) \alpha_{H}
$$

Thus, preemption of class litigation through waiver agreements is more likely as the difference between the waiver demand prices of high-damage and low-damage victims decreases, and as the efficient class size declines relative to the total and to the viability threshold. Conversely, preemption of class litigation becomes less likely as the waiver demand price spread increases and as the efficient class size increases relative to the initial class size and the viability threshold. Preemption of class litigation is efficient if

$$
\left(N_{0}-N^{*}\right)(\beta L-\alpha L)+N^{*}(\beta H-\alpha H)>0,
$$

and since this may not be satisfied when it is profitable for the injurer to preempt the class, inefficient preemption can occur. 
